\title{
The life cycle functional response of Rhopalosiphum padi (L.) to higher temperature: territorial expansion of permanent parthenogenetic development as a result of warmer weather conditions
}

\author{
Przemysław Strażyński, Maria Ruszkowska* \\ Department of Entomology, Institute of Plant Protection - National Research Institute, \\ Władysława Węgorka 20, 60-318 Poznań, Poland
}

Received: September 30, 2014

Accepted: April 9, 2015

\begin{abstract}
Bird cherry-oat aphid (Rhopalosiphum padi L.) is the most abundant aphid species on cereals in Poland. It represents approximately $80 \%$ of all cereal aphids. Its anholocyclic forms are the most important vectors of Barley yellow dwarf virus (BYDV). These forms are new among the Polish population of R. padi. Their changes in development are the result of higher temperatures. High spring and summer temperatures initiate a change in the run of $R$. padi's life cycle, which begins to reproduce by means of permanent parthenogenesis. In autumn, this aphid does not fly back to the primary host but inhabits wild grasses. It is in autumn that winter cereals emerge. This results in what appears to be a new problem because this viral infection spreads in warmer environmental conditions.
\end{abstract}

Key words: BYDV, life cycle, Rhopalosiphum padi, temperature

\section{Introduction}

The sufficiently high daily mean temperature in the summer $\left(\geq 25^{\circ} \mathrm{C}\right)$, is related to Poland's critical position which comprises a border between warm temperature climate and boreal climate as well as annualiso-amplitudes of $20^{\circ}$ and $23^{\circ} \mathrm{C}$ (Köppen 1936). The climate is becoming increasingly continental from West to East. The initiation of the change in the development of the bird cherry-oat aphid Rhopalosiphum padi (L.) from cyclic into permanent parthenogenetic forms is conditioned by temperature in the spring and summer. A daily mean temperature $\geq 25^{\circ} \mathrm{C}$ for a minimum of 3 days switches the holocyclic form into the anholocyclic one within $100 \%$ of the population (Ruszkowska 1990). Temperature thresholds limit geographical distribution of these aphid forms. Anholocyclic forms of $R$. padi are the most important vectors of Barley yellow dwarf virus (BYDV). This virus disease is a new problem in cereal protection, in warmer regions of Poland (Strażyński et al. 2011).

The aim of this study was to observe the territorial expansion of anholocyclic forms of R. padi in Poland.

\section{Materials and Methods}

Studies were conducted at several levels:

1. Observational studies were done from 2005 to 2010 on the territorial expansion of aphids, potential vectors of BYDV, colonising winter barley. The studies were based on surveys of crops in autumn in different regions of the country: Opolskie (A), Wielkopolskie (B), Pomorskie (C), Warmińsko-Mazurskie (D), Mazowieckie (E), and Podkarpackie (F) (Fig. 1). The sample consisted of 100 plants of winter barley with feeding aphids. Crops were harvested on the diagonal.

2. Collections were made of 150 aphid samples from each region in which the anholocyclic forms were distinguished on the basis of embryo color (Lowles 1995).

3. Registration was done of the number and time of $R$. padi flights using the Johnson suction trap, in Poznan (B), in the 2005-2010 study period. The anholocyclic forms were separated.

4. Temperatures that caused developmental changes of $R$. padi were registered. Data from local weather stations were used.

\section{Results and Discussion}

Between 2005-2010, as a result of field observations in the studied regions, the appearance of aphids in varied intensities on winter cereals was recorded (Table 1). The highest number of aphids was registered in 2006 in the Opolskie region, and in 2008 in the Wielkopolskie region. These regions are the warmest areas in Poland.

Anholocyclic forms occurred most frequently in 2007, with the exception of the Pomorskie region, where no aphids were found. In 2005-2006 in the Warmińsko-Mazurskie region, and in 2008 in the Pomorskie region, aphids were first found on winter barley, but they were 


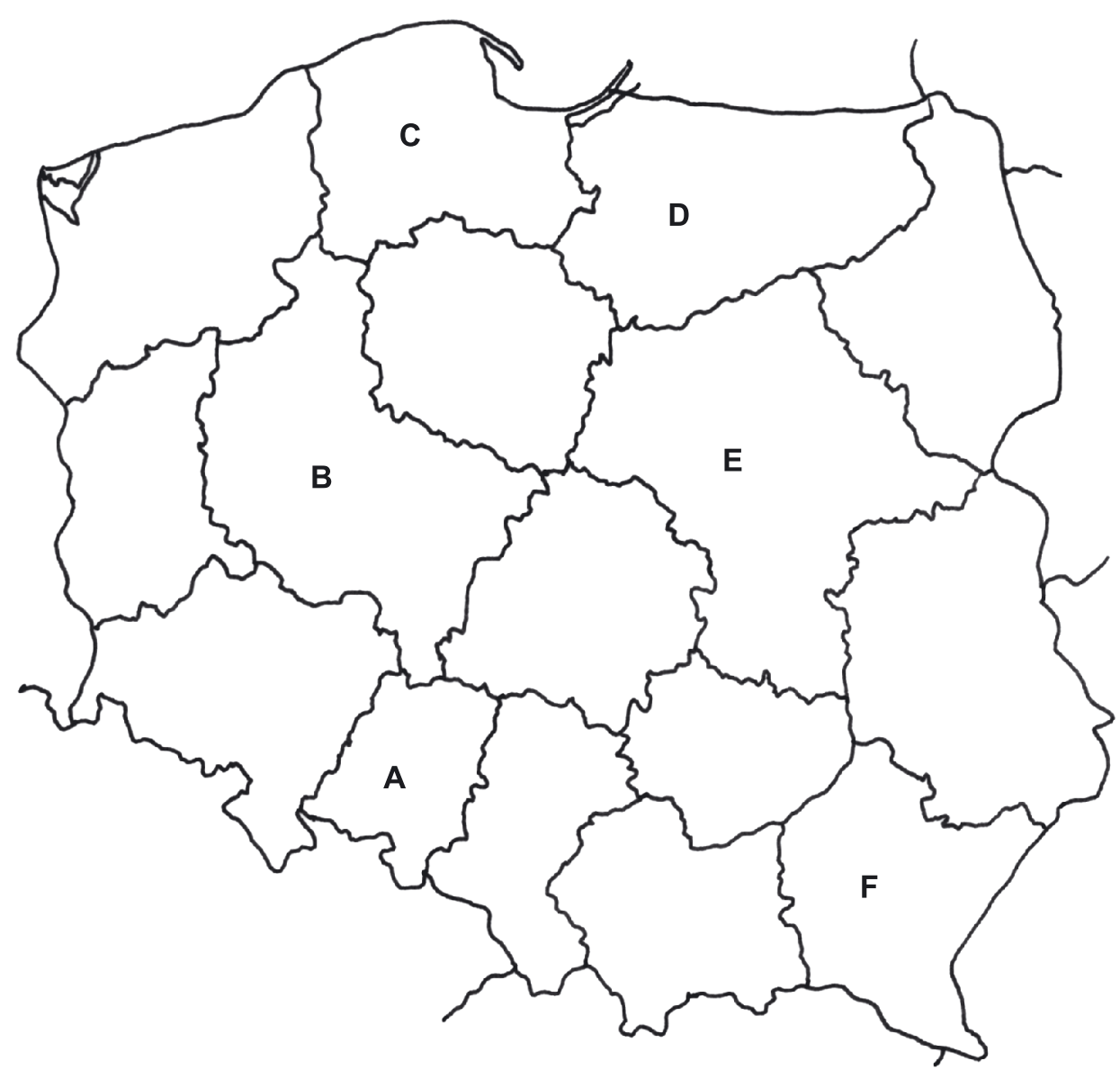

Fig. 1. Regions of Poland (A-F) selected for the observations

Table 1. Rhopalosiphum padi in numbers on winter barley in autumn, including anholocyclic forms of aphids tested (among 150 aphid individuals) in different regions of Poland, 2005-2010

\begin{tabular}{|c|c|c|c|c|c|c|}
\hline \multirow{2}{*}{ Region } & \multicolumn{6}{|c|}{ Year } \\
\hline & 2005 & 2006 & 2007 & 2008 & 2009 & 2010 \\
\hline \multirow{2}{*}{ A } & 188 & 326 & 114 & 299 & 227 & 203 \\
\hline & $31^{*}$ & $22^{*}$ & $107^{*}$ & $39^{*}$ & $31^{*}$ & $30^{*}$ \\
\hline \multirow{2}{*}{ B } & 210 & 213 & 57 & 327 & 162 & 281 \\
\hline & $32^{*}$ & $34^{*}$ & $61^{*}$ & $32^{*}$ & $24^{*}$ & $31^{*}$ \\
\hline \multirow[b]{2}{*}{$\mathrm{C}$} & \multirow{2}{*}{ - } & \multirow{2}{*}{-} & \multirow[b]{2}{*}{-} & 27 & 60 & 35 \\
\hline & & & & $0^{*}$ & $7^{*}$ & $18^{*}$ \\
\hline \multirow{2}{*}{$\mathrm{D}$} & 16 & 111 & 26 & 29 & 42 & 24 \\
\hline & $0^{*}$ & $0^{*}$ & $10^{*}$ & $10^{*}$ & $12^{*}$ & $10^{*}$ \\
\hline \multirow{2}{*}{ E } & 17 & 64 & 47 & 42 & 48 & 29 \\
\hline & $11^{*}$ & $11^{*}$ & $13^{*}$ & $10^{*}$ & $21^{*}$ & $11^{*}$ \\
\hline \multirow{2}{*}{ F } & 173 & 206 & 82 & 136 & 98 & 128 \\
\hline & $10^{*}$ & $31^{*}$ & $62^{*}$ & $31^{*}$ & $29^{*}$ & $19^{*}$ \\
\hline
\end{tabular}

*anholocyclic forms among 150 holocyclic aphid individuals

holocyclic forms. In subsequent years anholocyclic forms had already been recorded. These regions are located in the north and north-western parts of the country.

In the 2005-2010 time period, a total of 68071 R. padi were caught in the suction trap. This number constituted from $44.1 \%$ in 2007 to $62.8 \%$ in 2005 of all the registered aphids. The top two periods in which there was an increase in this species in catches were during summer dispersions and autumnal remigration (Fig. 2). Until recent- ly, the maximum percent of aphid catches was registered in autumn in comparison to the flights registered several years ago when they were most intense (Ruszkowska 1987; Strażyński 2005).

The number of diversified autumnal morphs and forms of $R$. padi in suction trap catches is presented in table 2 . In recent years, a slightincrease in the participation of anholocyclic forms has been observed. A reverse tendency was noted in relation to the number of males. 
$\square 2005 \square 2006 \square 2007 \square 2008 \square 2009 \square 2010$

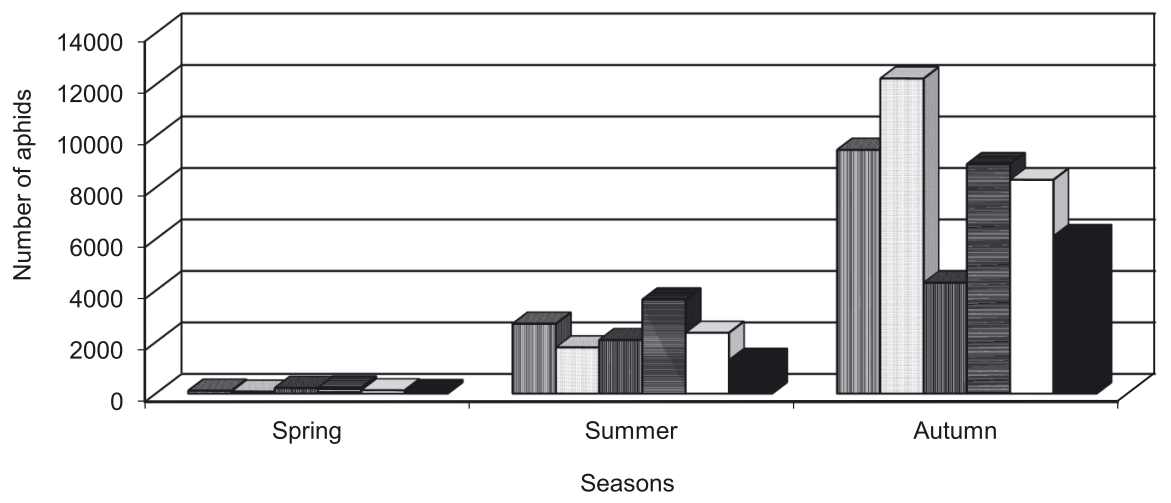

Fig. 2. Rhopalosiphum padi flight dynamics in suction trap catches in 2005-2010

Table 2. Population structure of Rhopalosiphum padi's autumnal morphs in suction trap catches in Poznań, 2005-2010

\begin{tabular}{lcccccc}
\hline \multirow{2}{*}{ Morphs } & \multicolumn{7}{c}{ Years } \\
\cline { 2 - 7 } & 2005 & 2006 & 2007 & 2008 & 2009 & 2010 \\
\hline \multirow{2}{*}{ Gynoparae } & 8,600 & 10,134 & 4,702 & 9,233 & 7,058 & 4,894 \\
& $83.7 \%$ & $74.3 \%$ & $79.5 \%$ & $81.4 \%$ & $84.6 \%$ & $81.3 \%$ \\
\hline \multirow{2}{*}{ Males } & 965 & 1,654 & 1,163 & 1,141 & 684 & 536 \\
& $9.4 \%$ & $12.1 \%$ & $19.6 \%$ & $10.0 \%$ & $8.2 \%$ & $8.9 \%$ \\
\hline \multirow{2}{*}{ Anholocyclic } & 704 & 1,852 & 49 & 972 & 592 & 584 \\
forms & $6.8 \%$ & $13.5 \%$ & $0.8 \%$ & $8.5 \%$ & $7.1 \%$ & $9.7 \%$ \\
\hline
\end{tabular}

The time of male appearance was also delayed till the 2nd half of October, while a few years ago it was early September (Ruszkowska 1987).

The first anholocyclic forms in suction trap catches were recorded in 2006 - on 26 August, the last ones in 2007 - on 24 September, and in 2009 - on 27 September. The first males were observed in 2006 on 4 September. In the two final research years, the males were observed for the last time - respectively 17 and 16 September.

In 2005-2010, the presence of a heat-induced development of the anholocyclic forms of $R$. padi was recorded. Figure 3 shows the number of days with a mean daily temperature $\geq 25^{\circ} \mathrm{C}$ in the studied regions.
Given the course of January and July isotherms and lines of the flow of warm air masses, it may be concluded that the south-west area is the warmest region in Poland. It was in this part of Poland that anholocyclic R. padi and BYDV infections were recorded for the first time and the infections tended to occur more often (Ruszkowska 2002). The course of the temperature allowed for estimating the presence of aphids on winter cereals in particular regions. The development of anholocyclic forms of $R$. padi in the autumn is possible only under specific temperature conditions. Development in autumn could be a kind of indicator of climate changes. Temperature monitoring is a key element for forecasting the occurrence of these important developmental changes in aphids. With infor-

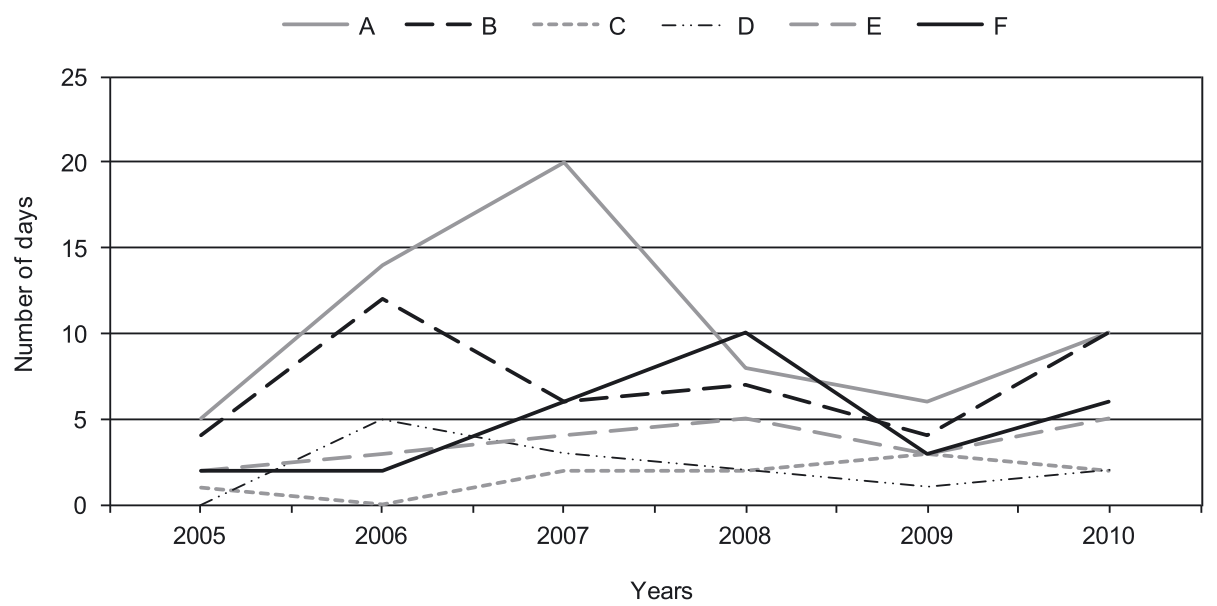

Fig. 3. Number of days in May and June with temperature inducing the change in the life-cycle of Rhopalosiphum padi, daily mean $\geq 25^{\circ} \mathrm{C}$ in $2005-2010$ in diverse regions (A-F) of Poland 
mation about the temperatures, it is possible to conclude that anholocyclic R. padi appear in different years and different regions, and certainly, R. padi come in a large part from the domestic population. So far it has been demonstrated, that in Poland, the development of anholocyclic forms depends on two factors: temperature and age of the host plant. On secondary hosts anholocyclic $R$. padi develops in higher temperatures during the spring and summer. In the autumn, aphids feed on young parts of plants, in a way that inhibits their return to the holocyclic development (Ruszkowska 2002, 2007).

The presence of aphids on winter cereals is not tantamount to the occurrence of BYDV - aphids would have to be infected by viruses. However, in warmer countries, the occurrence of anholocyclic forms determines the BYDV epidemiology (Pons et al. 1995). The increase in the occurrence of anholocyclic forms of R. padi and the following geographical expansion of $R$. padi, testify to the accelerated pace of the natural evolutionary global warming trend. The presence of anholocyclic forms of R. padi could be an indicator of climate change (Rispe et al. 1998).

\section{References}

Köppen W. 1936. Das geographische System der Klimate. p. 1-44. In: "Handbuch der Klimatologie". ["Handbook of Climatology"] (W. Köppen, G. Geiger, eds.). Gebrüder, Borntraeger, Berlin, Germany, 44 pp.

Lowles A. 1995. A quick method for distinguishing between the two autumn winged female morphs of the aphid Rhopalosiphum padi. Entomologia Experimentalis et Applicata 74 (1): 95-98.

Pons X., Comas J., Albajes R. 1995. Occurrence of holocyclic and anholocyclic populations of Rhopalosiphum padi and Sitobion avenae (Hom., Aphididae) in the northest of Spain. Journal of Applied Entomology 119 (1-5): 1171-1175.
Rispe C., Hulle M., Gauthier J-P., Pierre J-S., Harrington R. 1998. Effect of climate on the population of sexuals in the autumn flight of the aphid Rhopalosiphum padi L. Journal of Applied Entomology 122 (1-5): 129-136.

Ruszkowska M. 1987. Population dynamics of cereal aphids in Poland from 1973 to 1984. p. 209-218. In: "Population Structure, Genetics and Taxonomy of Aphids and Thysanoptera" (J. Holman, ed.). Proceedings of International Symposium, Smolenice, Czechoslovakia, September 9-14, SPB Academic Publishing, 542 pp.

Ruszkowska M. 1990. Forecasting the abundance of Rhopalosiphum padi (L.) by means suction trap catch and meteorological data. Acta Phytopathologica et Entomologica Hungarica 25 (1-4): 447-451.

Ruszkowska M. 2002. Przekształcenia cyklicznej partenogenezy mszycy Rhopalosiphum padi (L.) (Homoptera: Aphidoidea) - znaczenie zjawiska $\mathrm{w}$ adaptacji środowiskowej. [Alternation in parthenogenesis of the aphid Rhopalosiphum padi (L.) (Homoptera: Aphidoidea) - creative adaptation of resource]. Rozprawy Naukowe Instytutu Ochrony Roślin 8, $63 \mathrm{pp}$.

Ruszkowska M. 2007. Across the transformation life cycle of Rhopalosiphum padi (L.) (Homoptera: Aphidoidea): coevolution with temperature. Rozprawy Naukowe Instytutu Ochrony Roślin 15, 60 pp.

Strażyński P. 2005. Dynamics of aphid seasonal flights in Johnson suction trap in Poznań in 2003-2004. p. 175-183. In: "Aphids and Other Hemipterous Insects" (B. Wilkaniec, ed.). Vol. 11. Akademia Rolnicza, Poznań, 212 pp.

Strażyński P., Ruszkowska M., Jeżewska M., Trzmiel K. 2011. Evaluation of the autumn infection of winter barley with Barley yellow dwarf viruses transmitted by anholocyclic forms of bird cherry-oat aphid Rhopalosiphum padi (L.) in Poland. Journal of Plant Protection Research 51 (3): 314-321. 